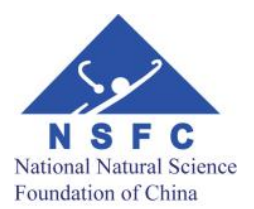

University

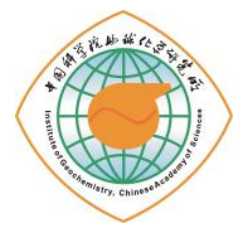

\title{
Report for the Puding Government on the China- UK Karst Knowledge Exchange Project
}

\author{
Ying Zheng ${ }^{\mathrm{a}^{*}}$, Larissa A. Naylor ${ }^{\mathrm{a}}$, Susan Waldron ${ }^{\mathrm{a}}$, David M. Oliver ${ }^{\mathrm{b}}$, Tao Peng ${ }^{\mathrm{c}}$ \\ ${ }^{a}$ School of Geographical and Earth Sciences, University of Glasgow, Glasgow G12 8QQ, UK; \\ ${ }^{b}$ Faculty of Natural Sciences, University of Stirling, Stirling, FK9 4LA, UK; \\ 'Puding Karst Ecosystem Research Station, State Key Laboratory of Environmental \\ Geochemistry, Institute of Geochemistry, Chinese Academy of Sciences, Puding, 562100, China \\ Contact: Ying Zheng (Ying.Zheng@glasgow.ac.uk)
}

\begin{abstract}
:
The report summaries the first stage output from the Knowledge Exchange (KE) research carried out in one of China's rural areas in the karst landscape, aiming to understand the local knowledge sharing dynamic and learning preference of stakeholders. A social science survey was carried out in November 2016 in 7 villages of Puding County to 15 county leaders, 8 town leaders and 24 village leaders along with 312 farmers. This survey helped us to gain an appreciation of existing environmental understanding of different public groups, how they currently learn and how they would like to learn about new scientific findings that influence farming and land management practice in Puding County. This report documents a high-level summary (the data is analysed at the county level) about the land use practices of local science users, the KE approach preferred by different public groups and about how the science-policy-practice interface works in Puding county. With this report, and the discussions that stem from it with Chinese practitioners and leaders, we anticipate that more effective communication can be fostered between scientists and the public science users, and between different user groups to increase the use of scientific advances in county to farm scale policy and practice.
\end{abstract}




\section{Project aims}

This study was commissioned as part of the China-UK Critical Zone (CZ) Project for the karst hydrology-biogeochemical interface. This study explores what knowledge exchange activities can facilitate communication and understanding between academics and the non-academic groups of the karst CZ science research in the context of Chinese culture, especially in China rural areas.

\section{Funders}

This publication was produced under grant NE/N007425/1 which was awarded by the Natural Environment Research Council (NERC) of the UK, and grant 41571130074 awarded by the National Natural Science Foundation (NSFC) of China.

\section{Team \& Authors}

The UK project team consists of Prof. Susan Waldron (Principal Investigator), Dr. Larissa Naylor (Co-Investigator) and Dr. Ying Zheng (KE associate) from the University of Glasgow, and Dr. David Oliver (Co-Investigator) from the University of Stirling. The Chinese project team consists of Prof. Xi Chen (Principal Investigator) from Hohai University, Prof. Shijie Wang (CoInvestigator) and Dr. Tao Peng from Puding Karst Ecosystem Research Station.

This publication is produced by Ying Zheng, Larissa A. Naylor, Susan Waldron, David M. Oliver and Tao Peng. It can be cited as: Zheng, Y., Naylor, L.A., Waldron, S., Oliver, D.M., Peng T. 2017. Report for the Puding Government on the China-UK Karst Knowledge Exchange (KE) project. DOI: $10.31223 /$ osf.io/7pcnu

Chinese Citation: 郑颖, Naylor, L.A., Waldron, S., Oliver, D.M., 彭蹈. 2017. 中英喀斯特地球 关键带研究普定县知识交流报告. DOI: $10.31223 /$ osf.io/7penu

Author contributions: Y.Z., L.A.N., S.W. and D.M.O. conceived the presented study design. Y.Z. L.A.N, D.M.O. and P.T. conducted the fieldwork and data acquisition. Y.Z. performed data analysis. Y.Z., L.A.N., S.W. and D.M.O. drafted the report and provided critical revision. P.T. contributed to the final revision of the report.

\section{Acknowledgements}

The analysis draws on a survey conducted by the University of Glasgow, and assisted by Institute of Geochemistry Chinese Academy of Sciences (IGCAS), Puding Karst Ecosystem Research Station (P-KERS), and Anshun College in Guiyang.

P-KERS provided valuable support in facilitating access to all groups surveyed: government departments, town and village leaders and local residents (farmers and non-farmers). Many government officers in the towns and villages helped to encourage their residents to complete the surveys and they also participated in the surveys themselves. Fujun Yue (UoG), students from (IGCAS) and staff from P-KERS helped us conduct the surveys providing practical and academic support. Significant help also came from undergraduate students of Anshun College; they were trained by the UK team and then carried out surveys with local farmers. They explained the survey's aims and helped the local farmers complete the surveys. 


\section{Executive summary}

This report is a first stage output from the Knowledge Exchange ${ }^{1}(\mathrm{KE})$ research package within the China-UK Karst CZ project in Puding County, Guizhou Province, China. At this stage, the research focuses on understanding the scientific understanding, land use practices and $\mathrm{KE}$ practice experience of local farmers and villagers, as well as village, town and county level leaders. They live in the studied karst landscape and will benefit from the scientific research results of the NERC-NCSF funded research projects in the county. Part of the requirement of the research projects is to help use the scientific results to inform farm and land management policy, and the day-to-day farming practices of residents. To do this most effectively, we need to understand the current ways in which Chinese leaders, farmers and residents learn from scientists and what are key issues facing them that our research can help them with. Thereforewe need to first understand their current knowledge of the karst landscape they live in and how their activities affect it. The primary interest of this research was to gain understanding of the experience and preference of farmers, residents and leaders for the types of KE practice that can best support them. This understanding can provide valuable information for the future design of KE delivery and KE outputs arising from our projects and those of others. The report introduces the project (Section 1), outlines the research methods (Section 2) and presents preliminary results from the KE survey (Sections 3, 4, 5 and 6), which was carried out in November 2016.

The critical zone (hereafter, CZ) is scientifically defined as the "heterogeneous, near surface environment in which complex interactions involving rock, soil, water, air, and living organisms regulate the natural habitat and determine the availability of life-sustaining resources" (National Research Council America, 2001²). This portion of the Earth surface sustains nearly all terrestrial life and support almost all human activity ${ }^{2}$. Our Karst CZ project in Puding County focuses on water availability and quality, and how presence and movement of water in the karst landscape influences surface vegetation. This new knowledge will help the local residents deal with current and future environment challenges through improving our understanding of the processes and pressures on critical ecosystem services ${ }^{3}$ this landscape (and the economic benefits of these) provides to society. Improved understanding can help influence shifts in water management and farming practice to help alleviate poverty in this rapidly developing region. As part of the project there is an on-going KE research package that is designed to help ensure research results can be more effectively delivered to those who need them. To facilitate more effective delivery of the expected research outputs from this project, we carried out a baseline survey in November 2016 to learn about the local residents, their needs, farming practices and understanding of landscape processes, along with the KE methods and preferences of different public groups (residents, farmers and village, town and country leaders). The full details are described in Section 1 Introduction.

The survey results showed water quantity and/or quality for irrigation was one of the biggest concerns for Puding farmers (Section 3). Many of them did not have proper catchment knowledge or appear to poorly understand how their activities influenced catchment processes and water quality, and thus their livelihoods (Section 4). Yet, the majority of farmers expressed a keen interest in learning about different farming, land and water management practices - few of these felt that had received much training in this regard. The lack of catchment knowledge and perceived lack of training by farmers suggests that there is a need of better KE for Puding farmers.

\footnotetext{
${ }^{1}$ Knowledge exchange (KE) is defined as the two-way process of shaping, sharing and the scientific research process so that the science produced can be readily used policymakers, practitioners and society (Fazey et al. 2013). KE largely focuses on identifying and overcoming the barriers to knowledge exchange between them (after Cvitanovic et al., 2015).

${ }^{2}$ Basic Research Opportunities in Earth Science. National Academies Press. doi:10.17226/9981.

${ }^{3}$ Ecosystem services are the benefits people obtain from ecosystems, which include provisioning services; regulating services; cultural services; and supporting services. Millennium Ecosystem Assessment (MA). 2005. Ecosystems and Human Well-Being: Synthesis [1]. Island Press, Washington.
} 
We asked the different survey groups how they felt farmers would best learn new skills and understanding of catchment processes to improve farm productivity and environmental sustainability at the same time - results differed between groups. Most surveyed farmers preferred farm visits to learn new knowledge, while posters and written materials were the least favoured (Section 5). Furthermore, a better conceptual understanding of the science-policypractice interface across levels of governance (i.e. county - town - village - farmer and scientists) in Puding County was generated from the survey. This suggested that, as part of future KE activities, more direct communication between scientists and farmers, using on-farm training methods, would be most beneficial (Section 6).

\section{Key findings}

\section{Question 1. Houzhai catchment demographics}

- The majority of 312 farming respondents in the seven villages surveyed are female $(67 \%)$, $82 \%$ of all respondents were older than 40 and only $2.6 \%$ of respondents were between 18 25 years old. The county level statistician confirmed this is representative of the local population.

\section{Question 2. Houzhai catchment farming and land management practice}

- Farmers felt that the top two issues affecting their farming practice (and thus income) were inadequate labour and lack of water for irrigation.

- Village and town leader data supported the farmer data showing that income, water related issues (availability and quality) and soil erosion were the greatest pressures on farmers.

\section{Question 3. Environmental understanding of farming community}

- Drought (or the extremely dry periods) was reported by the local farmers to be the major environment issue affecting their farming.

- While water quantity and quality are the major concerns across villages, more than $50 \%$ of the farmers did not think that their farming practice could affect water source downstream from the farm, suggesting they have limited catchment knowledge and lack understanding of how their activities impact on the environment that sustains their society.

- Similarly, $60 \%$ of farmers were not aware of pathogens in animal waste that can cause illness in humans; also suggesting that there is limited understanding of the impacts of their agricultural practices on their health and well-being.

Question 4. Learning and training experience and needs

- Farmers felt (at least $40 \%$ of 310 respondents) they would benefit from more training to improve the productivity of their farms (and by association to lessen their environmental impact); but that training had not been sufficient in the past.

- Farmers strongly valued on-farm visits from experts; this was their most-favoured way to learn new knowledge (60\% of respondents preferring farm visits compared to $30 \%$ favouring training courses).

- Government (village and town level) leaders preferred to share knowledge with farmers through providing training ( $86 \%$ of town leaders and $64 \%$ of village leaders), with farm visits as the second choice.

- Other forms of KE such as posters or written instruction were not popular with farmers or county level leaders, and had mixed views from town and village leaders.

\section{Question 5. Science-policy-practice interface}

- The science-policy-practice interface in Puding County for knowledge exchange was documented. From discussions with practitioners from county to village levels, that it is mainly the county level office that organizes training for farmers by scientists directly, with less training of town and village leaders. Within villages, the village leaders interact more directly with farmers to provide farming advice (i.e. there is limited engagement between 
county level staff and farmers, nor between them and town and village leaders). Scientists are involved in the county-level government-organized training, but typically lack of direct communication with farmers about the design of these training programmes for farmers. For farmers, a lack of time was a clear barrier to uptake of training, as for each day spent training, there was less time to earn a living from the fields. 


\section{Table of Contents}

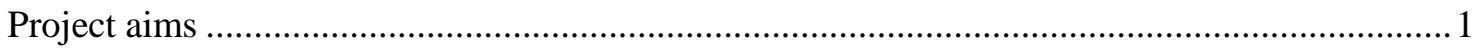

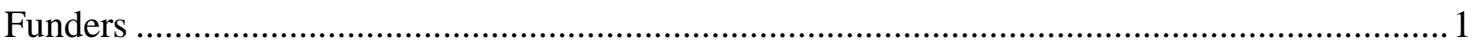

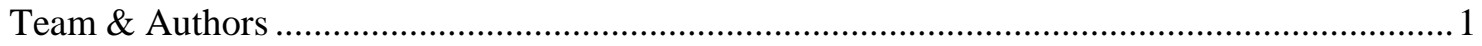

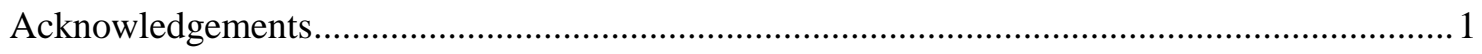

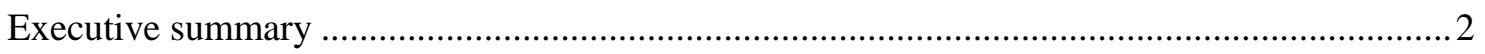

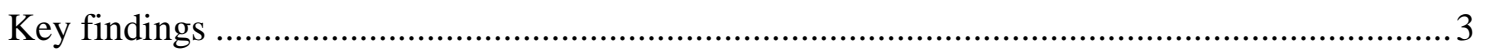

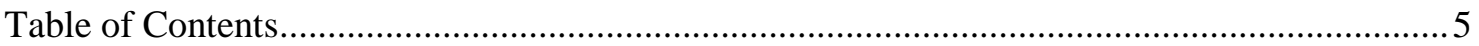

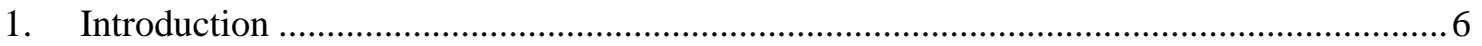

1.1 Brief introduction to the importance of CZ ecosystem................................................. 6

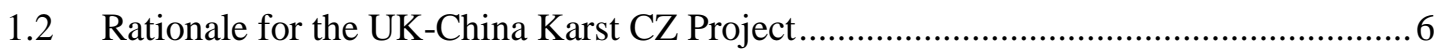

1.3 Summary of the CZ science activities being undertaken in Puding County................... 7

1.4 Research aims of knowledge exchange (KE) in Puding County .................................. 8

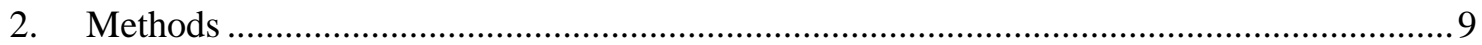

3. Demographics and farming and land management practice .............................................. 11

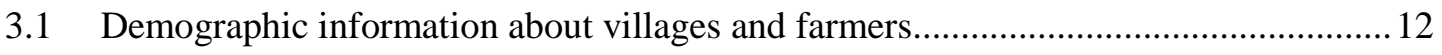

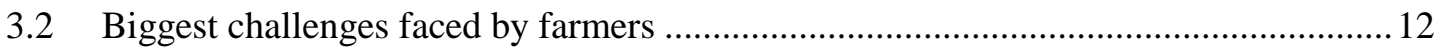

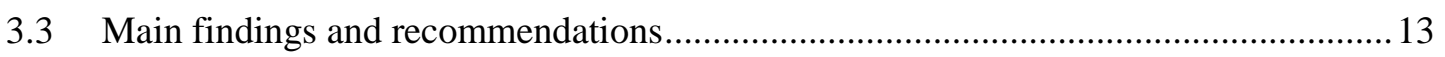

4. Catchment and human impact on the environment understanding .................................... 13

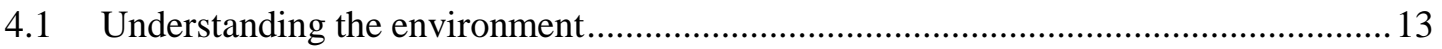

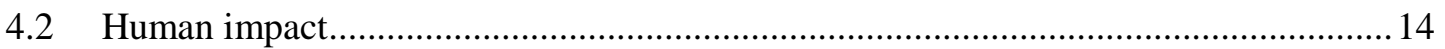

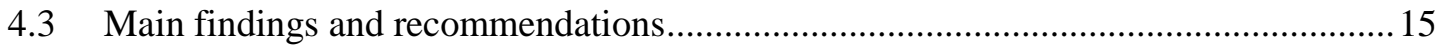

5. Knowledge exchange practice and learning preferences ................................................. 15

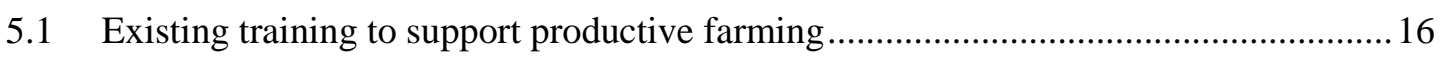

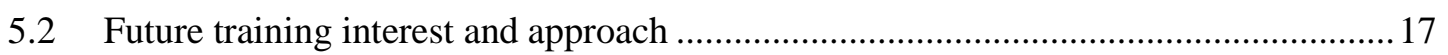

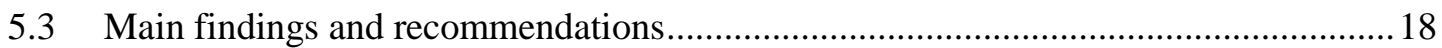

6. Science-policy-practice interface in Puding County ........................................................ 18

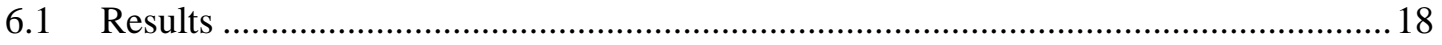

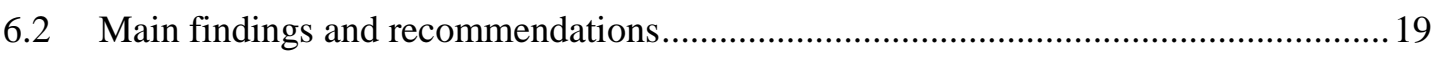

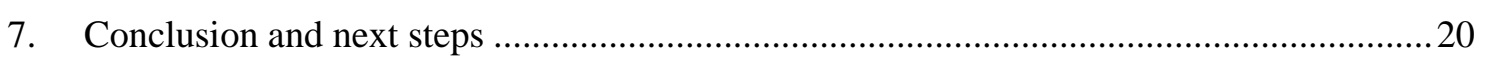

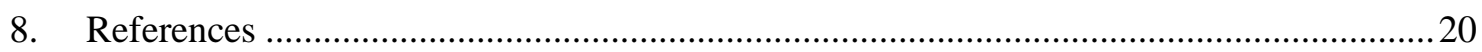




\section{Introduction}

\subsection{Brief introduction to the importance of $\mathrm{CZ}$ ecosystem}

We now understand that the surface of the Earth (the soils and vegetation) and the underlying rock (the geology) influence the quality and quantity of soil and water, including groundwater, which moves through our environment and sustains critical functions for society, such as a good supply of clean water. This portion of the Earth's surface has been scientifically termed the 'Critical Zone' (hereafter, CZ). It is considered to be a coupled chemical, biological, physical, and geological system with processes interacting to support life at the Earth's surface ${ }^{4,5}$, and supports almost all human activity from the resources it provides. The different components of the CZ interact and human activity can strongly influence this both positively and negatively. For ecosystems to be sustainable and productive, society needs the negative human impacts on the landscape to be reduced, through sustainable land and water management, so that the critical resources the system provides to society (e.g. potable water), and activities like farming, are unaffected. However, the $\mathrm{CZ}$ can also be under pressure if it is disrupted either directly (e.g. chemical pollution) or indirectly (e.g. climate change) from human activity, and it can adversely affect its functioning and thus the economic, health and social value that society can derive from their environment. To understand how the $\mathrm{CZ}$ is affected by current human and climate stressors and how it may respond to future stressors, we need to better understand how such systems function now. Closely related to understanding how the Houzhai catchment functions scientifically is learning how society benefits from, impacts and is impacted by the current environmental conditions (e.g. is the water clean or are they getting ill).

\subsection{Rationale for the UK-China Karst CZ Project}

Why in China: Rural China is an area of rapid population and economic growth where many live under the poverty line. Local residents face significant environmental challenges (water quality, water availability, karst desertification) that are currently affecting the ecosystem services that the landscape provides - and thus their current and future livelihoods. This is a joint research programme between UK and China, which is supported by the Newton Fund ${ }^{6}$. A requirement of Newton funding is that the research must meaningfully build capacity and help alleviate poverty in developing regions of the world, in this case China.

Our research will focus on two of these challenges: water availability and quality, and how movement of water in the CZ influences surface vegetation (and thus farm productivity). Crucial to this research is that the underlying rock is mostly limestone, forming a karst system, which rapidly removes water from the surface to an underground system which means there is limited natural water storage on land. Karst systems (and the agricultural systems and communities they support) are wide-spread in China and so have been chosen for the studied area. Karst is also widely distributed world-wide; a study of groundwater - surface interactions and effects on farming communities is thus also relevant to many other regions.

Why the catchment scale and why Houzhai catchment in particular? Relationships between human use of water and land often happen at the local scale (e.g. on an individual farm) but have an impact at a much larger spatial scale (e.g. across a catchment). By examining water dynamics and gaining an understanding of human activities in a catchment, we can start to identify linkages

\footnotetext{
${ }^{4}$ Lin. Earth's Critical Zone and hydropedology: concepts, characteristics, and advances. Hydrol. Earth Syst. Sci., 14, 25-45, 2010

${ }^{5}$ Brantley, S.L., Godhaber, M.B., Ragnarsdottir, K.V., 2007. Crossing disciplines and scales to understand the Critical Zone. Elements 3, 307-31.

${ }^{6}$ The Newton Fund aims to promote the economic development and social welfare of either the partner countries or, through working with the partner country, to address the well-being of communities. It will do so through strengthening partner country science and innovation capacity and unlocking further funding to support this work. China is one of the partner countries.
} 
between water quantity and quality and human activity. This can help us to better manage the environment. Houzhai is also a particularly useful catchment to study these interactions due to the long-history of scientific study of water, soil and agriculture in the catchment and the acute need of the population to improve their livelihood. The people living in the Houzhai catchment generally live-off-the-land as subsistence farmers, but environmental degradation here is affecting their livelihoods. When the land surface is repeatedly heavily-cultivated and/or farming practices are not well-suited to fragile karst ecosystems, problems can arise such as poor water quality, often with very-high levels of nitrate (a chemical that is found in fertiliser), that is harmful to people and natural resources like fish. Karst soils are often poorly developed and thin. Clearance of native vegetation for intensive agricultural practice has eroded soil and exposed rock, greatly limiting the agricultural capacity of the land. These impacts are occurring now, before the currently observable and future predicted effects of climate change are considered. For example, how and when rain is delivered to the catchment has been changing such that water is not as available (or not available at the right time) as before. Thus there have also been water shortages, and this led to crop failure and thus a loss of food and economic capacity for those living in the catchment. Secure ecosystem services are fundamental to human life and if compromised those affected will be unable to rise above poverty as they will be struggling to live beyond daily existence. Science, among other initiatives, must help them improve their land and water management practices, so that the socio-ecological resilience of these fragile karst landscapes are sustained under the increasing population and climate change pressures.

CZ research has been carried out in the Houzhai catchment for about 20 years; valuable science findings by Puding Karst Ecosystem Research Station and other research groups have already help improve farming practice, such as the road-pool rainwater collection for surface water utilization project provides valuable experience and demonstration models for solving the problem of drought and water shortage in the karst area and is widely promoted. The science in this project builds upon and extends this research by improving our understanding of the characteristics and stresses on the groundwater network and its connectivity with the land surface - and thus how these interactions can be better managed to improve socio-ecological resilience of the catchment. Beyond the catchment, this scientific research will also contribute to the global $\mathrm{CZ}$ research network by generating models of how a karst $\mathrm{CZ}$ currently functions, and by investigating how the sensitivity of $\mathrm{CZ}$ functioning to different environmental drivers.

\subsection{Summary of the CZ science activities being undertaken in Puding County}

This project is one of five projects jointly funded by the Newton Fund/Natural Environment Research Council in the UK and the National Natural Science Foundation in China. Two of the five projects involve research in Puding County; this report focuses on the knowledge exchange component of one project. The over-arching objective of this research project is to provide a scientific evidence-base to inform management of the ecohydrologically-sensitive culturallyimportant karst landscapes that Puding County is comprised of. This research will help ensuring the security of crucial provisioning (water supply; food production) and regulating (water quality; diffuse pollution attenuation) ecosystem services that karst landscapes provide to China. Important here is that the bedrock is limestone and so water can move through it quickly and is typically held in underground caverns, with limited surface storage. Hydrologists and environmental scientists are working together to create a model of water movement and storage, and water quality, in Puding County. This requires intensive collective of multiple types of data across the catchment over different spatial and temporal scales to measure variability in water flow and varying land uses that may influence water quality, such as the timing of fertiliser application or harvesting relative to rainfall patterns. These data will be used to make recommendations on how the land and water can be managed more sustainability to improve the health and livelihoods of residents. This project has five work packages, as outlined in Figure 1 below. 
Work Package Management Structure \& Interactions

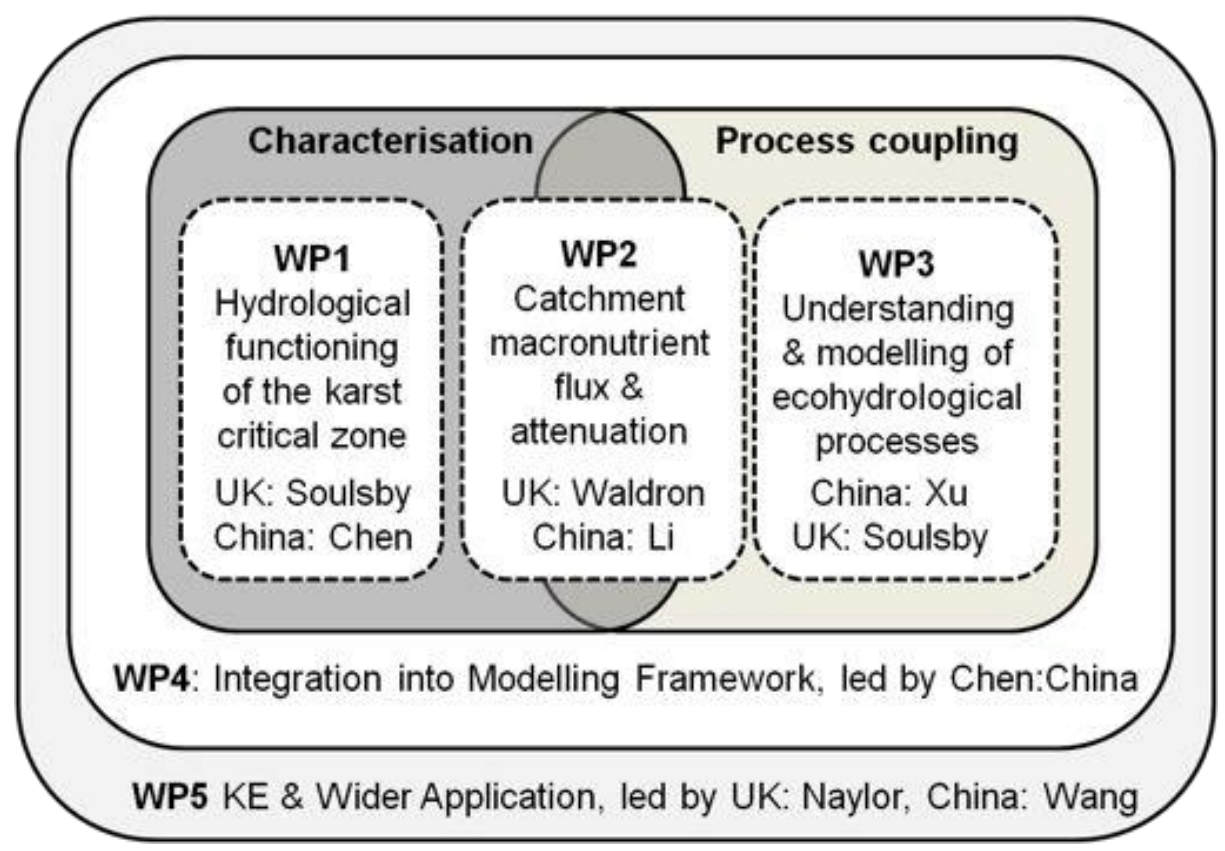

Figure 1. Diagram outlining the scientific work packages in this project.

\subsection{Research aims of knowledge exchange (KE) in Puding County}

For the scientific research to benefit society (and thus fulfil the requirements of the Newton funding), it is important that the improved catchment understanding from this scientific research project reaches those who manage the environment and tend the land. To do this effectively we must gain an appreciation of who the different users of the research are, what their baseline understanding of the catchment is and how they like to learn. Thus, in addition to the scientific research, there is a KE work package (WP5 in Figure 1) that is designed to provide a baseline understanding of the different potential users of the outcomes of this research. In this research project, the producers are UK and Chinese scientists, and the users are mainly government and residents who live in and manage the landscape. The KE work package was added to help understand and broker between these two groups, to better ensure that the outputs of this research fits the needs of users in Puding County and that a system is established to help share the new knowledge effectively. To do this, we need to engage with different users groups (residents, farmers and village, town and county leaders) to better understand:

Question 1. Farm community demographics are important background information to help place the results of the other primary research questions in context.

Question 2. Farming and land management practice. What the roles and needs of the different users are; how their activities interact with the environment, and to what extent they have developed catchment knowledge and use this knowledge to inform their day to day activities? This can help us to better understand which groups will benefit most from the research outputs by understanding their greatest pressures and current catchment understanding and their current governance structure, so that we can best align our research outcomes to their needs.

Question 3. Catchment understanding. Through surveys we gathered data on how knowledgeable the farming community and wider residents (e.g. non-farming residents, village and town leaders) were about catchment processes and human impacts on the environment. These data are crucial to identifying which scientific results will be of the greatest help to local farming communities and at what level this information needs to be pitched. 
Question 4. Learning and training experience and needs. To determine what, if any, KE is currently carried out between the scientific and policy-practitioner communities and importantly, how the different user groups would like to learn about the results of our research project. These data are important to identify how we can facilitate effective KE delivery (e.g. what type of outputs or knowledge sharing method is preferred) of the science from this project. With this understanding, we can select and design the most appropriate approach to share our knowledge with different users.

Question 5. What is the current governance structure in Puding County and how is the science-policy-practice interface navigated on issues of water, land and farm management? Through surveys and semi-structured group interviews, we sought to gain insight into how this interface currently operates in Puding County, to identify which level of government the UK and Chinese scientists involved in this research project are best placed to share their findings.

These data also serve as a baseline for future KE activities in our project and/or by practitioners in China. A change in policy or farming practice may stem from the research and KE activities carried out in this project - by having some baseline data it may be possible for future studies to assess whether KE arising from this project leads to improved knowledge, policy or land management practices in Puding County. For example, we can better tailor the design for KE activities to align with what practitioners and farmers want within Puding County. We can also hopefully help identify which gaps in their catchment understanding our research findings can help address, or which farming practices such as fertiliser use may be affecting their productivity and negatively impacting on the environment. Moreover, this report also provides valuable insights that can support four other China-UK CZ projects funded by NERC-NSFC, one of which is being carried out in Guizhou Province, including some areas of Houzhai catchment.

\section{Methods}

During the summer and early autumn of 2016 a comprehensive social science survey was designed and ethics approval granted for this activity by the University of Glasgow's ethics committee. Questions were designed to address the five research questions outlined above. The questionnaires were developed by the scientists in the UK and Chinese teams, who were particularly involved in designing survey questions to help answer research questions 2 and 3 on farming practice, catchment understanding and human impacts on the environment. These questions were refined where required on arrival in China, taking advantage of local knowledge to improve the language of our questions to suit the local dialect.

Between 19 - 23 November 2016, a social science survey was carried out for four levels of governance (hereafter groups) in Houzhai catchment: county, town and village leaders and individual residents (who were a combination of farmers and non-farming residents including personal responses from village and town leaders). The three towns and seven villages were identified by the Chinese research team as locations within Houzhai catchment where most of the scientific research takes place and where monitoring stations are located, and where village leaders were supportive of the KE surveys. They were: Chenqi, Houzhai in Huangtong Town, Maguan, Jinhe, Mabao and Liugu in Maguan Town, and Dayou in Baiyan Town (Figure 2). 


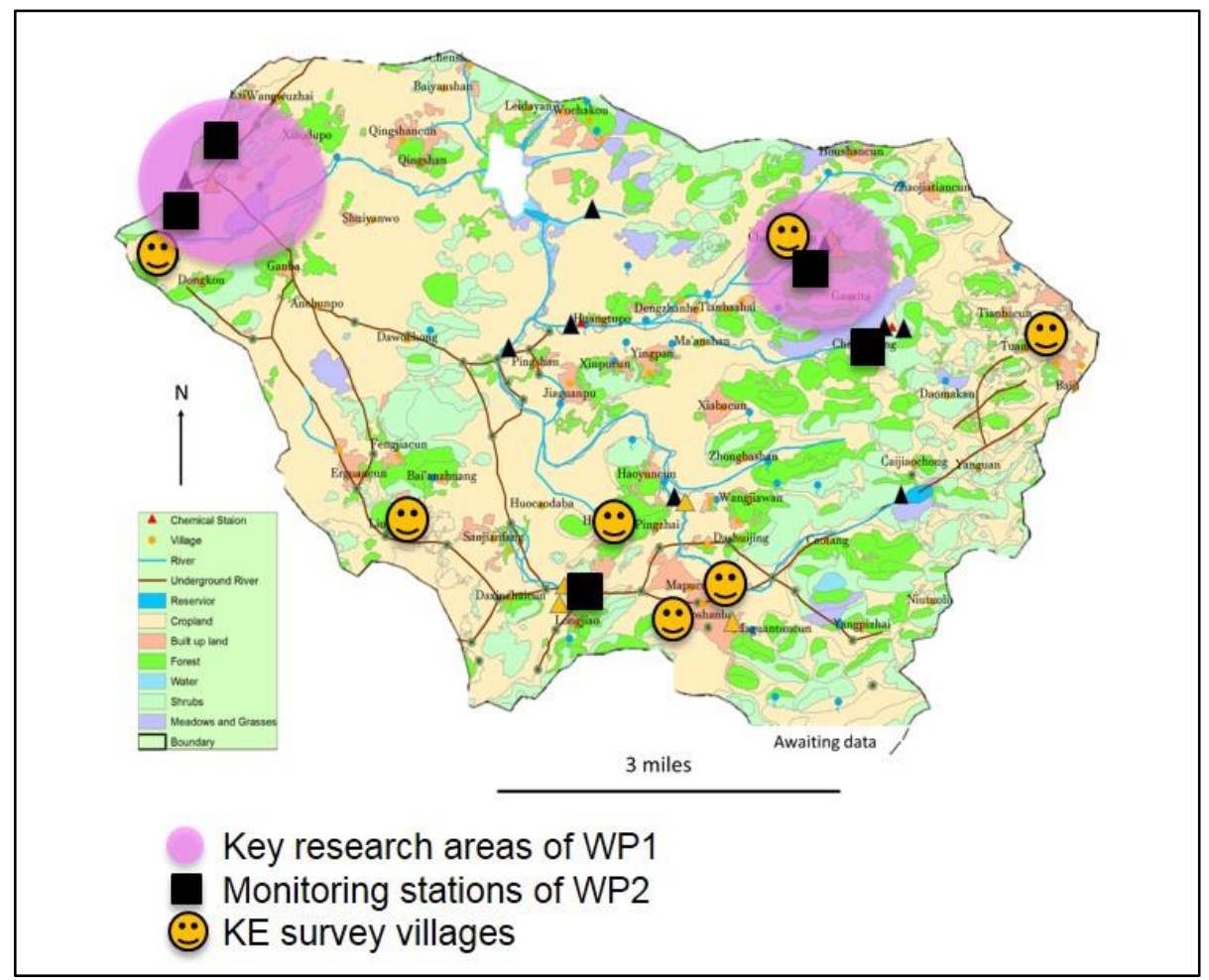

Figure 2. The Map of Houzhai catchment shows the seven villages surveyed for knowledge exchange (KE) understanding. The key research areas in WP1 are indicated by pink closed circles and monitoring stations in WP2 by black squares.

As part of this work package, we also sought to build capacity of local Chinese university students. Students from Anshun College attended a one-day training course led by the Universities of Glasgow and Stirling, and then served as research assistants during the course of our survey work. The students stayed at P-KERS; in the field they assisted farmers with understanding and filling questionnaires (Figure 3a). In total a maximum of 312 responses were collected from farmers, 24 from village leaders; 8 from town leaders, 15 from county leaders and 59 community surveys from non-farming residents (this included personal responses from village and town leaders where appropriate). The students also helped with data entry and preliminary analyses, giving them valuable experience in the collection, processing, analysis and presentation of social science data.

Questionnaires with both closed and open-ended questions were the main survey method for all groups. Between $20-60$ questionnaires were taken to both farmers and leaders in each village according to its population, with a target of sampling size of 50 farmers per village. The total number of survey questions per group and research question are outlined in Table 1 . In addition to surveys, semi-structured individual and/or group interviews were also conducted with government leaders from county, town and village levels to gather information about knowledgelearning activities produced for both leaders and farmers in Houzhai catchment (Figure 3b). The number of leaders interviewed varied between village and town (from two - six people), depending on the number of village leaders who were available. At county level, three different group interviews were carried out with between two to five people interviewed per group. In this report for the county leaders, the data from questionnaire survey and interview is combined for science-policy-practice understanding and not presented individually. 


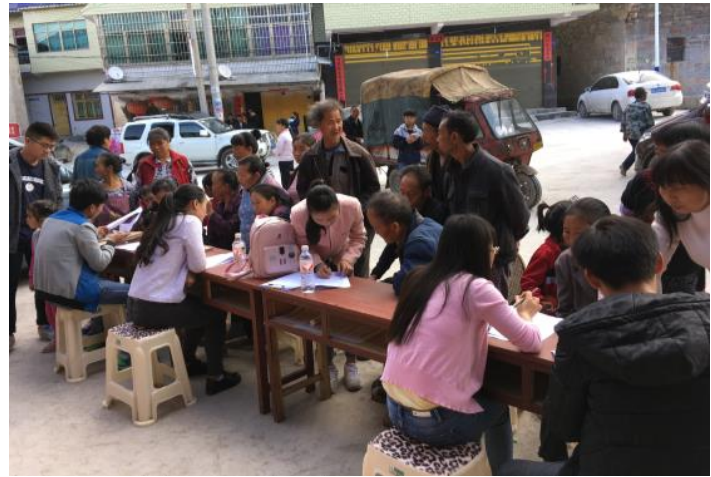

Figure 3a Local farmers filling in questionnaires with the help from students of Anshun College.

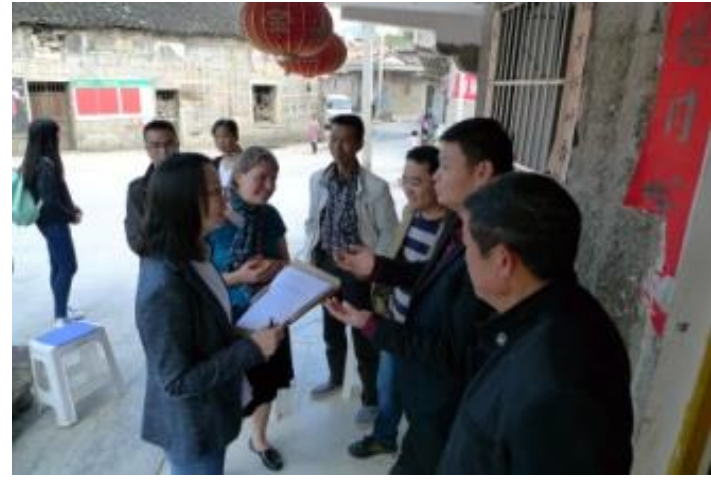

Figure 3b Village leaders were gathered for group interviews and their individual community surveys.

Table 1 Summary of survey questions by group and research question where leader surveys were carried out for three levels of governance (county, town and village) and community surveys were for non-farming residents (including personal responses from village and town leaders).

\begin{tabular}{lcccc}
\hline Category of survey questions & $\begin{array}{l}\text { Farmer } \\
\text { survey, no. } \\
\text { of questions }\end{array}$ & $\begin{array}{l}\text { County } \\
\text { leader } \\
\text { survey, no. } \\
\text { of questions }\end{array}$ & $\begin{array}{l}\text { Town and } \\
\text { village leader } \\
\text { survey, no. } \\
\text { of questions }\end{array}$ & $\begin{array}{l}\text { Community } \\
\text { survey, no. } \\
\text { of questions }\end{array}$ \\
\hline Total number of questions & 33 & 19 & 15 & 18 \\
\hline $\begin{array}{l}\text { Question 1. Demographics } \\
\text { Question 2. Farming/land }\end{array}$ & 6 & 2 & 1 & 1 \\
$\begin{array}{l}\text { management practice (e.g. } \\
\text { fertiliser management) }\end{array}$ & 13 & 1 & 3 & 4 \\
\hline $\begin{array}{l}\text { Question 3. Environment } \\
\text { understanding }\end{array}$ & 7 & $/$ & $/$ & 9 \\
\hline Question 4. learning/training & 7 & 4 & 2 & 4 \\
\hline $\begin{array}{l}\text { Question 5. Science-policy- } \\
\text { practice interface }\end{array}$ & $/$ & 7 & 7 & $/$ \\
\hline Question 6. Job background & $/$ & 3 & 1 & $/$ \\
\hline Question 7. Policy making & $/$ & 2 & 1 & $/$ \\
\hline Number of people surveyed & 312 & 15 & 32 & 59 \\
\hline
\end{tabular}

In this report we provide a high-level summary of the understanding of the surveyed residents, farmers and leaders in Puding County, thus the data is grouped for presentation in the level of town and village. More detailed analysis looking at similarities and differences within groups, such as comparisons between different villages and towns, is currently undergoing, and will be presented in the future KE materials and research articles.

\section{Demographics and farming and land management practice}

All groups surveyed were asked some basic demographic questions. Farmers were also asked about their own farming and land management practices, and leaders were asked about the activities of farmers in their communities. Non-farming residents were also asked about their 
personal activities that relate to land management (e.g. how they dealt with human and animal waste). The most pertinent results from these questions are presented in this section.

\subsection{Demographic information about villages and farmers}

The majority of 312 farming respondents in the seven villages surveyed are female (67\%), $82 \%$ of all respondents were older than 40 and only $2.6 \%$ of respondents were between $18-25$ years old. The county level statistician confirmed this is representative of the local population.

\subsection{Biggest challenges faced by farmers}

Data was collected on farmer and village and town perspectives on the greatest pressure on farmers within their jurisdictions. For the most of the Puding farmers, the lack of labour was the greatest concern (suggested by $45 \%$ of farmers) followed by the source of water for irrigation (including water quantity and/or quality, $28 \%)(n=311$, Figure 4$)$. Fertilisers and technology were challenging to some farmers but much less so compared to labour and water source.

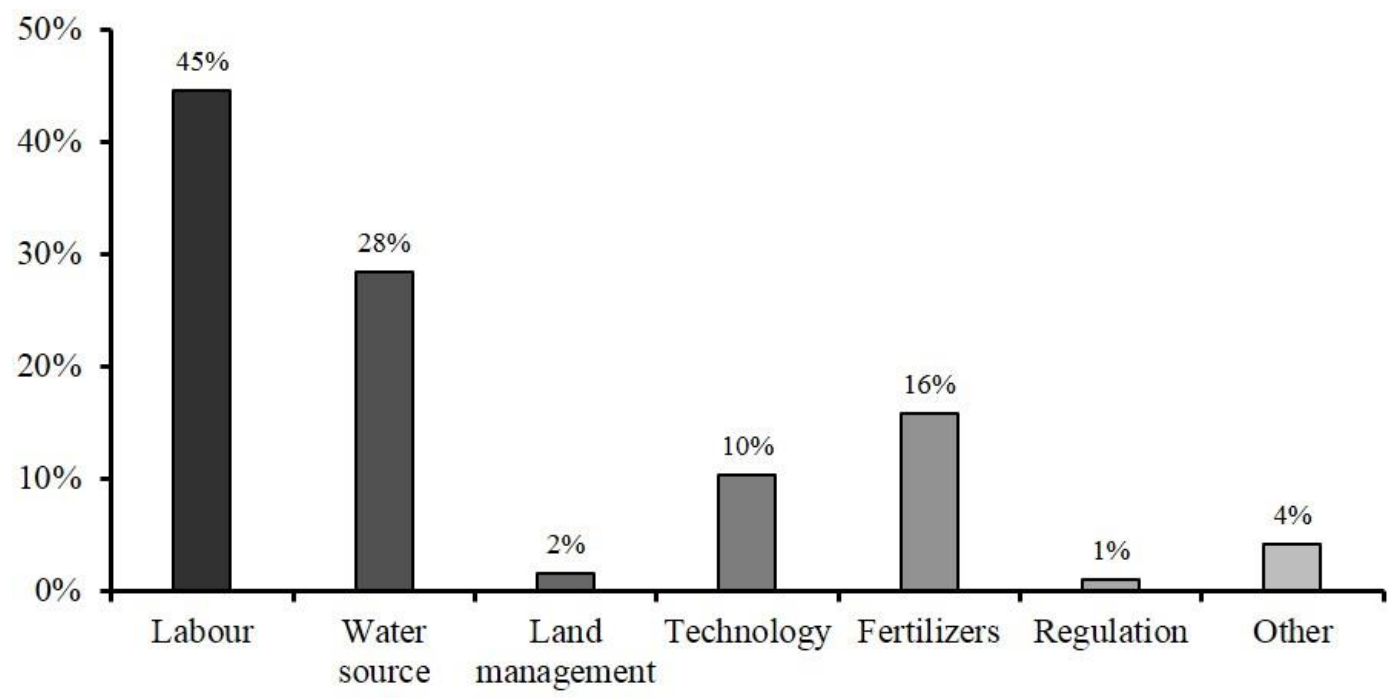

Figure 4. Farmer survey Q7: The biggest challenge for local farmers in farming $(\mathrm{n}=311$, multiple answers provided by farmers).

Village and town leaders were also asked what the greatest pressures on farmers in their communities were. The response from village and town leaders was consistent - both levels said that the greatest pressure on their farmers was an ability to earn an income (village: $79 \%$ of $n=$ 24 , town: $63 \%$ of $n=8$ ). Declining soil quality and water-related issues were equally suggested by $25 \%$ of town leaders as the greatest pressure on local farmers, while more village leaders said water-related issues (42\%) were of greater concern than soil erosion (33\%).

When farmers were asked about what was the most expensive part of their farming activity, it was readily apparent that fertilisers were the greatest expense (reported by $78 \%$ of 308 farmers), followed by tools and water for irrigation, respectively (Figure 5). This suggests that whilst labour and water are the greatest perceived challenges for farmers, the greatest expense is fertilisers. This correlates well with the town and village leader surveys that found 'earning an income' was the greatest pressure for farmers. The farmers thus appear to have three key pressures: labour shortage, water-related issues and the cost of fertilisers. Farmers were then asked what types of support and interventions could help improve the productivity and/or income generating capacity of their farms. The majority of respondents in all villages selected four of the five options: more financial support, more training, more labour and more land. 


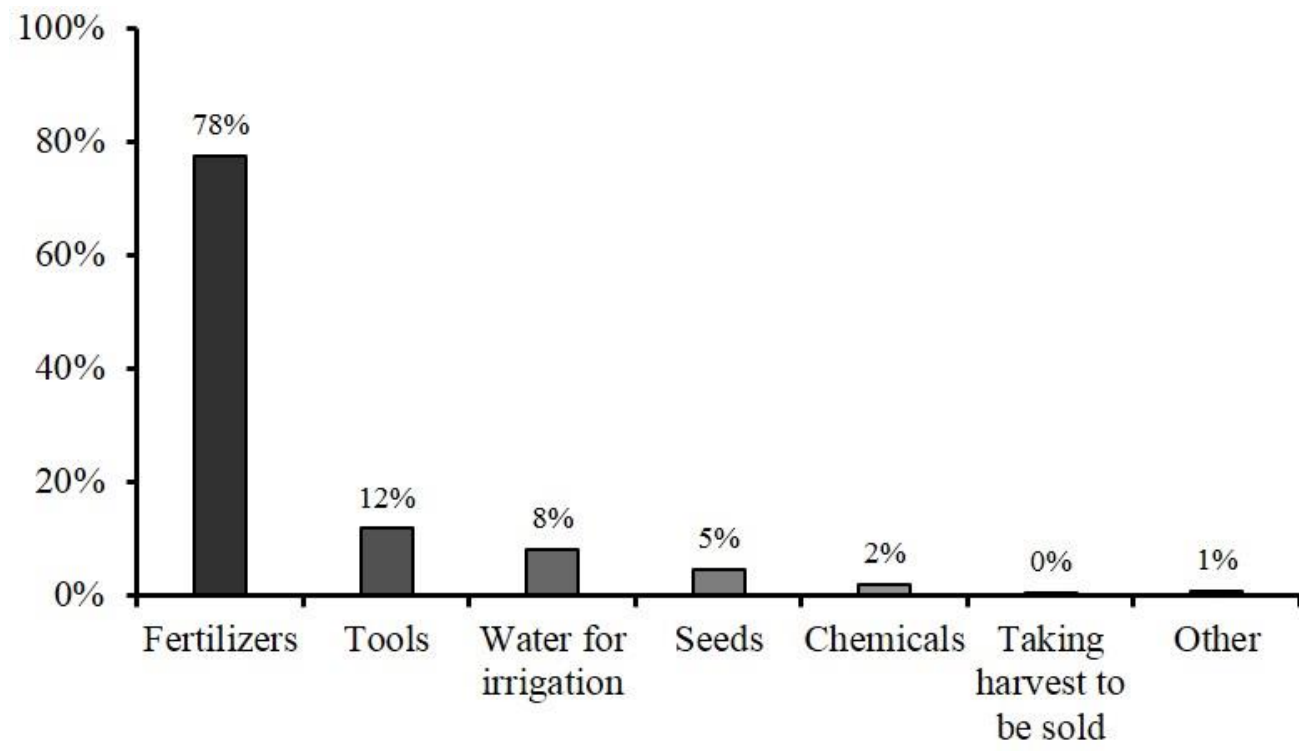

Figure 5. Farmer survey Q8: What is the most expensive part of your farming activities? $(\mathrm{n}=308$, respondents could choose more than one answer)

\subsection{Main findings and recommendations}

- In the seven surveyed villages in Puding County older residents are maintaining the land. This is a consistent and common trend in China due to an increasing number of young people working in cities. The villagers' age and the potential links with education level, may have impacts on how best to communicate and share new farming knowledge.

- Both farmers and village leaders reported water-related issues (quantity and quality) was a key issue affecting their farming practice (and thus income) or one of the greatest pressures on farmers, suggesting the need of improving water availability and quality for the better local agriculture development and farmers' life. Farming advice on water resource for irrigation, e.g. efficient ways of water storage and improving water quality via chemical/fertiliser management, would be helpful and much needed as water source is the second biggest challenge to farmers.

\section{Catchment and human impact on the environment understanding}

This topic was addressed in two ways: 1) catchment understanding: to assess how well farmers and residents understand how their local landscape works and 2) human impact: to gauge their awareness of whether their activities influence their environment (including clean water for humans).

\subsection{Understanding the environment}

Farmers were concerned about water source with $83 \%$ of them (total $n=309$ ) confirming drought was affecting their farming (Figure 6). Flooding was another major natural disaster affecting farming locally, confirmed by $33 \%$ of farmers across villages. However, soil erosion, landslides and forest fire did not appear often in these surveyed villages as concerns to the farmers. In response to the water shortage sometimes of the year, irrigation ditches were commonly built and used by farmers (37\%) for irrigation, and well water (ground water) was used by $33 \%$ of farmers for irrigation. 


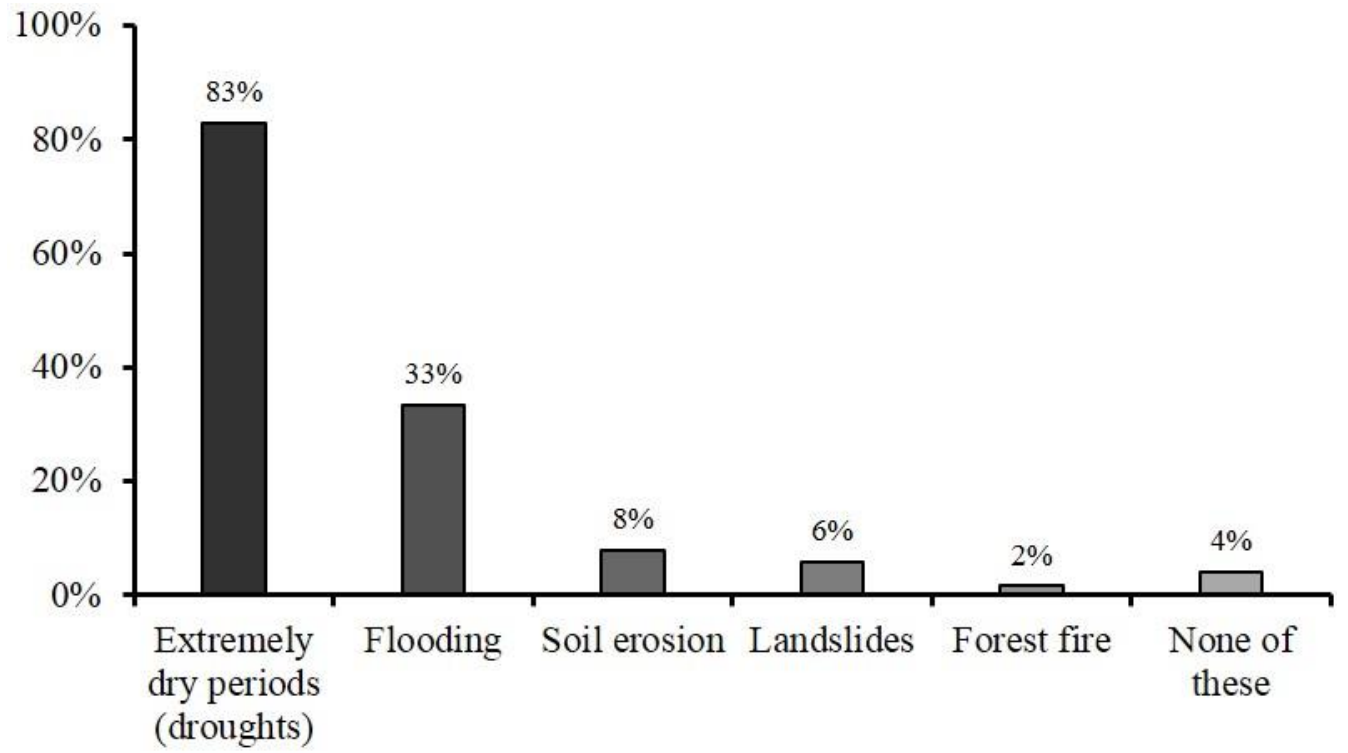

Figure 6. Farmer survey Q28: What types of environmental issues affect your farm? ( $\mathrm{n}=309$, multiple choice)

For the residents who were not farmers, we asked if they knew what their water source was. A common recognition of ground water as the main water source was shown between the communities with $64 \%$ of the residents (total $n=58$ ). However, there were $19 \%$ of the residents did not know what water source they were using.

If household water was dirty, most of the residents from the surveyed villages $(n=56)$ concerned about their health as the water making them ill (36\%) and the water was polluted (21\%). Less residents worried about if the water looked dirty or smelled.

\subsection{Human impact}

The question of whether farmers thought their farming activities (e.g. tilling, fertiliser use) would affect water source downstream from their land, can help to get the sense of farmers' scientific understandings about environment and catchment. Across all villages more farmers suggested no such effects from their farming $(58 \%$ of $n=309)$ (Figure. 7), suggesting they have limited catchment knowledge and lack understanding of how their activities impact on the environment that sustains their society.

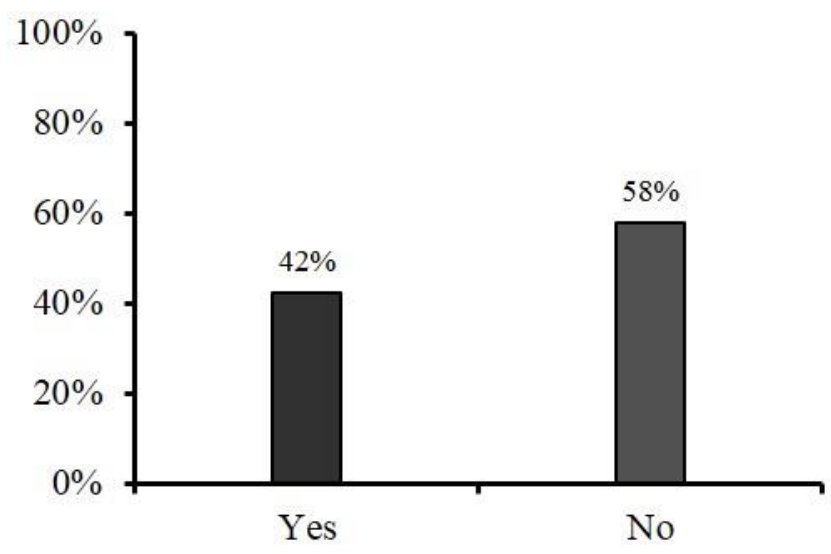

Figure 7. Farmer survey Q20: Do you think any of the farm activities (e.g. tilling, fertiliser or chemical use) you do on your land affect anything down the hill from your farm? $(n=309)$ 


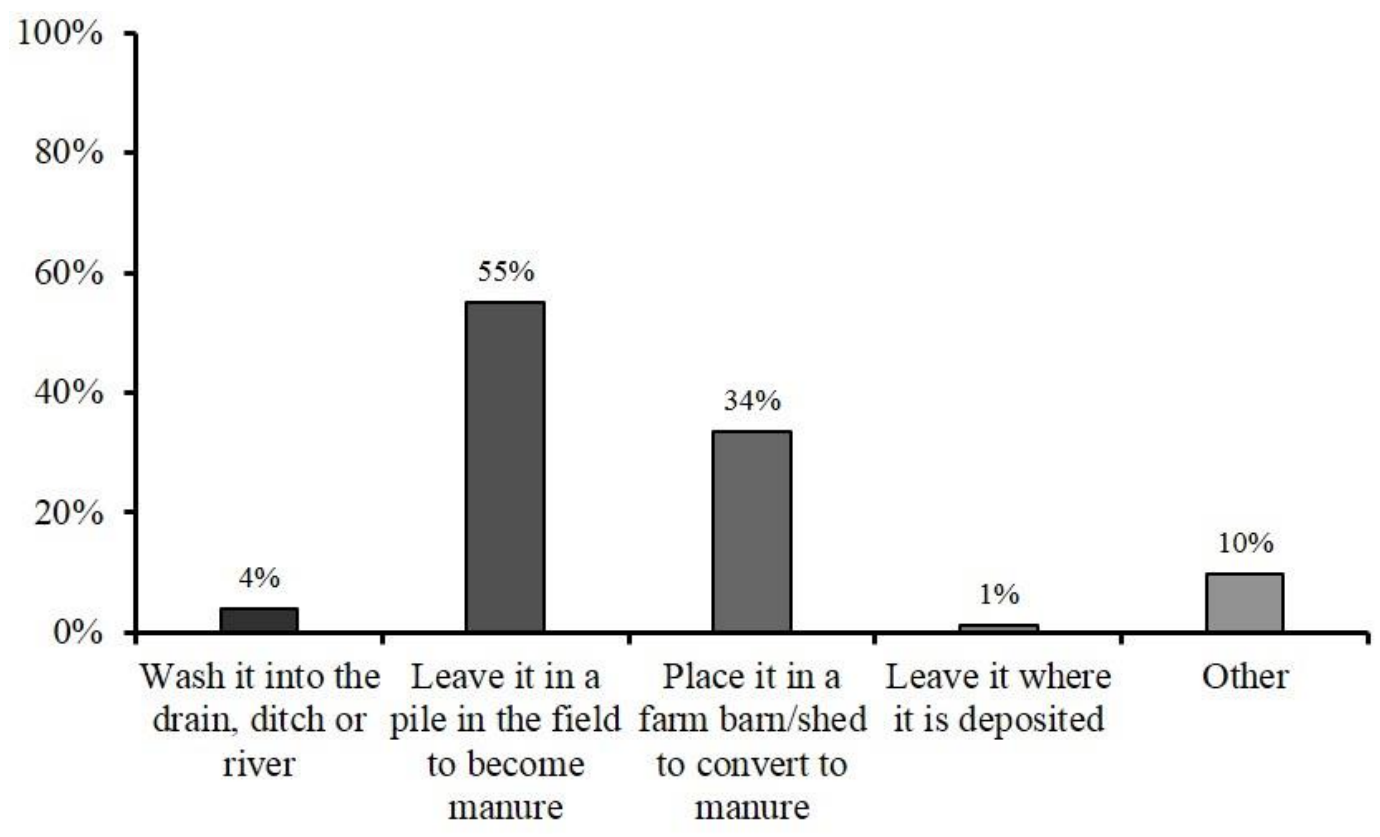

Figure 8. Farmer survey Q13: What do you do with your animal waste? $(\mathrm{n}=311$, multiple choice)

Furthermore, we asked if farmers had been encouraged to manage fertilizer and/or manure, with $62 \%$ of the surveyed farmers (total $\mathrm{n}=307$ ) reporting no such experience. This is consistent with the result that $60 \%$ of them (total $n=308$ ) did not have awareness of pathogens in animal waste. Furthermore, we asked the farmers who kept farm animal how they dealt with animal waste, most of them $(55 \%$ of total $n=311)$ reported they left it in a pile in the field to become manure, with less farmers (34\%) placing it indoor to produce manure (Figure 8). However, there were still 5\% of farmers washed the waste directly into drainage or left it unattended.

\subsection{Main findings and recommendations}

- The farmers' concerns with water quantity and quality for irrigation come with the frequent droughts in these villages. Although less often reported, flooding is another natural disaster affecting farming. These concerns indicate that scientific research is needed to help understand hydrological connections and water availability (in the perspective of quantity and quality) for better ecological services.

- Farmers in these seven villages do not have much knowledge about catchment environment. Thus the relevant education or training may encourage them to foster better farming practice to protect the local ecosystem.

- Training and promotion of manure/fertilizer management to farmers would be recommended to develop a better way of animal waste treatment. This may help to reduce manure-induced water pollution and the amount of commercial fertiliser required (which was the most expensive part of farming).

\section{Knowledge exchange practice and learning preferences}

In response to this topic, questions were asked to farmers and government leaders respectively (Table 2, Table 3), to understand: 1) what was the current training situation (e.g. how much training was provided to farmers, and existing training methods), and 2) what learning methods were preferred by farmers. 
Table 2 Summary of questions in farmers' survey related to KE practice

\begin{tabular}{lc}
\hline Category in farmer survey & No. \\
\hline Existing KE practice & 2 \\
Interest/need in learning & 3 \\
Preferred methods & 1 \\
Barrier to learning & 1 \\
Total & 7 \\
\hline
\end{tabular}

Table 3 Summary of questions in leader committee's survey related to KE practice

\begin{tabular}{lc}
\hline Category in town/village leader survey & No. \\
\hline Experience in KE with farmers & 2 \\
Experience in KE with scientists & 1 \\
Implementing policy & 8 \\
Total & 11 \\
\hline
\end{tabular}

\subsection{Existing training to support productive farming}

We assessed how farmers are currently trained/supported for productive farming, and asked town/village leaders about what advice about new farming practice was provided. A large percentage of farmers from all 7 villages $(71 \%$ of total $n=310)$ indicated no previous support, either financial- or training-related (Figure 9). Of the farmers who had previously received support to help improve their farming practice, $24 \%$ were financially-supported whilst $13 \%$ received training.

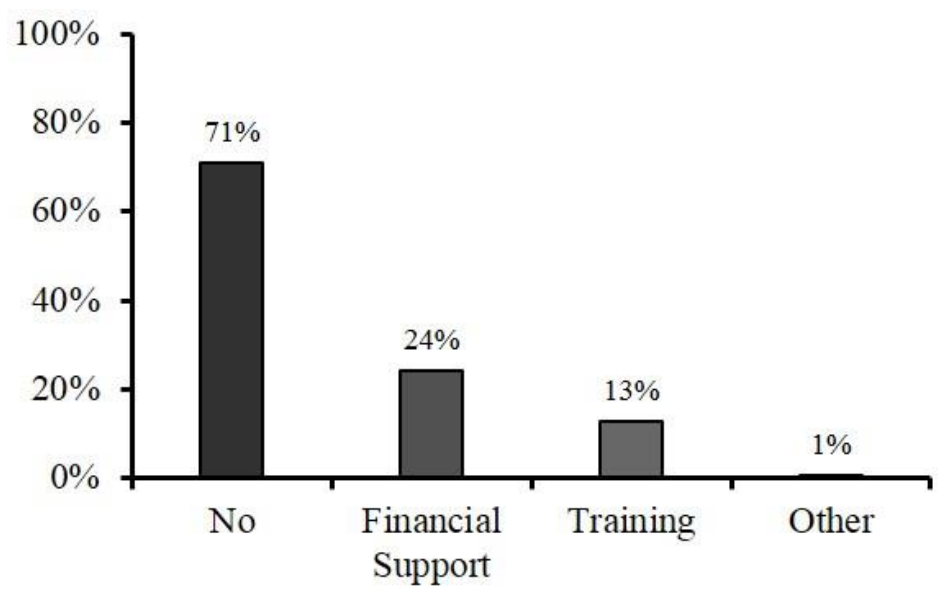

Figure 9. Farmer survey Q10: Have you ever received training or financial support from the government before? If yes, what kind of support have you been given? $(n=310$, multiple choice $)$

All town and village leaders (only except one town leader) reported they had provided advice on new farming practices to farmers. In general, there was a consistency between town and village leaders about what sort of advice was given, with most advice provided about new farming techniques, soil conservation, water conservation, fertilizer use and manure management. These 
differed from the farmers' response, which suggested most of them (62\% of 307) were not encouraged to manage fertilizer and/or manure.

While advice on farming practices were provided by local leaders, family still played an important role in spreading farming knowledge, with nearly all surveyed farmers ( $98 \%$ of total $n$ $=311$ ) from the seven villages reported they learned farming method from family (Figure 10). This was followed by learning from friends and fellow farmers (31\%). Only no greater than $10 \%$ of farmers suggested they also learned farming methods from either farm cooperatives or local government (including government agencies from city to village), another indicator of little training support the farmers feel they have previously received from the government. No farmers reported learning farming from university or college.

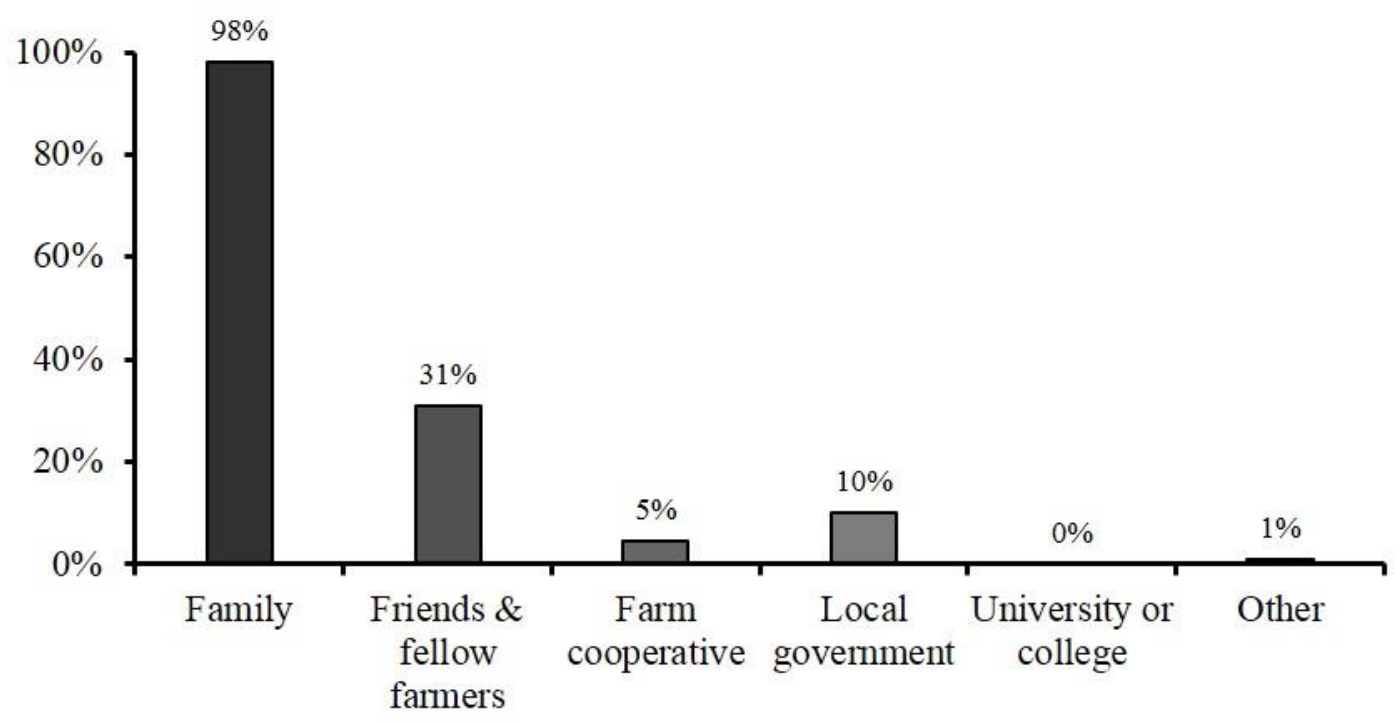

Figure 10. Farmer survey Q9: Where do you currently learn about farming methods? ( $\mathrm{n}=311$, multiple choice)

\subsection{Future training interest and approach}

Importantly, when farmers were asked if they would like to receive future training to help them farm differently, the response was overwhelmingly positive with $76 \%$ of all surveyed farmers (n $=300$ ) supporting for training. Similarly $71 \%$ of the farmers (total $n=293$ ) showed interest in learning more about how water moves through their environment. However it was noted among the surveyed farmers $(n=269)$ who showed interest in learning about environment and different farming methods, about 50\% reported they could not afford to take time away from the farm and/or their family (e.g. some farmers needed to take care of children).

Town and village leaders were also asked about the best ways to support farming to change their farming practice in the future. The response of leaders between town and village varied. Most of the town leaders interviewed (7 out of 9) felt training was a key method for improving farm practice, while financial support was the least favoured suggestion by the town leaders. However, among the village leaders $(\mathrm{n}=22), 64 \%$ suggested that financial support for farmers was the most crucial way, whilst half of them felt training was the best route.

There were different preferences from farmers to learn new farming knowledge than with the current training methods used by government leaders. Farm visit with someone to talk to was the most preferred method across all villages $(60 \%$ of total $n=287)$, followed by attending a training course $(30 \%)$ (Figure 11). Similar to government leaders, poster, picture books and written instructions were the least recommended methods to learn for farmers $(<20 \%)$. 


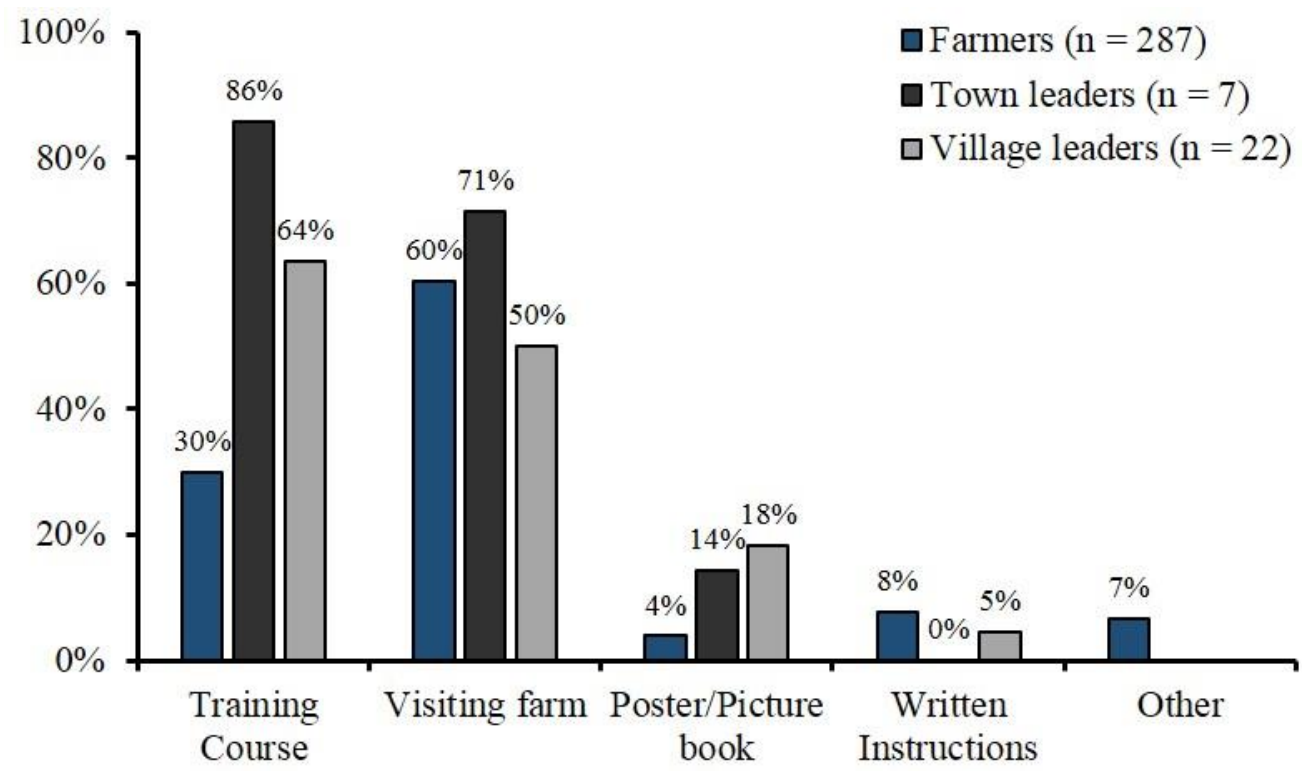

Figure 11. Farmer survey Q32 and village committee survey Q5: methods preferred by farmers to learn different farm practice/knowledge, and methods currently used by government leaders to provide advice on new farming practice (respondents could choose more than one answer).

For government leaders, training courses was the most popular way currently used to provide farmers with advice on farming practice (86\% of 7 town leaders and $64 \%$ of 22 village leaders), followed by farm visits ( $71 \%$ and $50 \%$, respectively) (Figure 11). Less than $20 \%$ of all groups felt that posters and picture books were effective to promote farming knowledge, whilst written instructions being the least favoured for all groups surveyed $(\leq 5 \%)$.

\subsection{Main findings and recommendations}

- More effective training for productive farming will be required, as it appeared that a large percentage of farmers do not believe they received any kind of support, and family is still the major source for farming knowledge. Effective communication and sharing/learning process had also been found to play an important role in promoting productive farming where they had some training - and the vast majority of farmers would welcome more training.

- The data show some differences of opinion between levels of government on the best support for farming. The preferred ways of sharing/learning are apparent from this survey and thus provides important insight into future government-public communication about farming practice.

- Instead of training courses, which was the approach currently used by government to share new farming practice, farm visiting by experts and talking in person was strongly recommended for farmers. Further, reading materials including posters, picture books and written instructions are not preferred in sharing knowledge and so may not be effective.

\section{Science-policy-practice interface in Puding County}

\subsection{Results}

An understanding how groups of scientists, government officers and practitioners interact and collaborate with each other was generated from the semi-structured individual and group interviews with the local government leaders. 


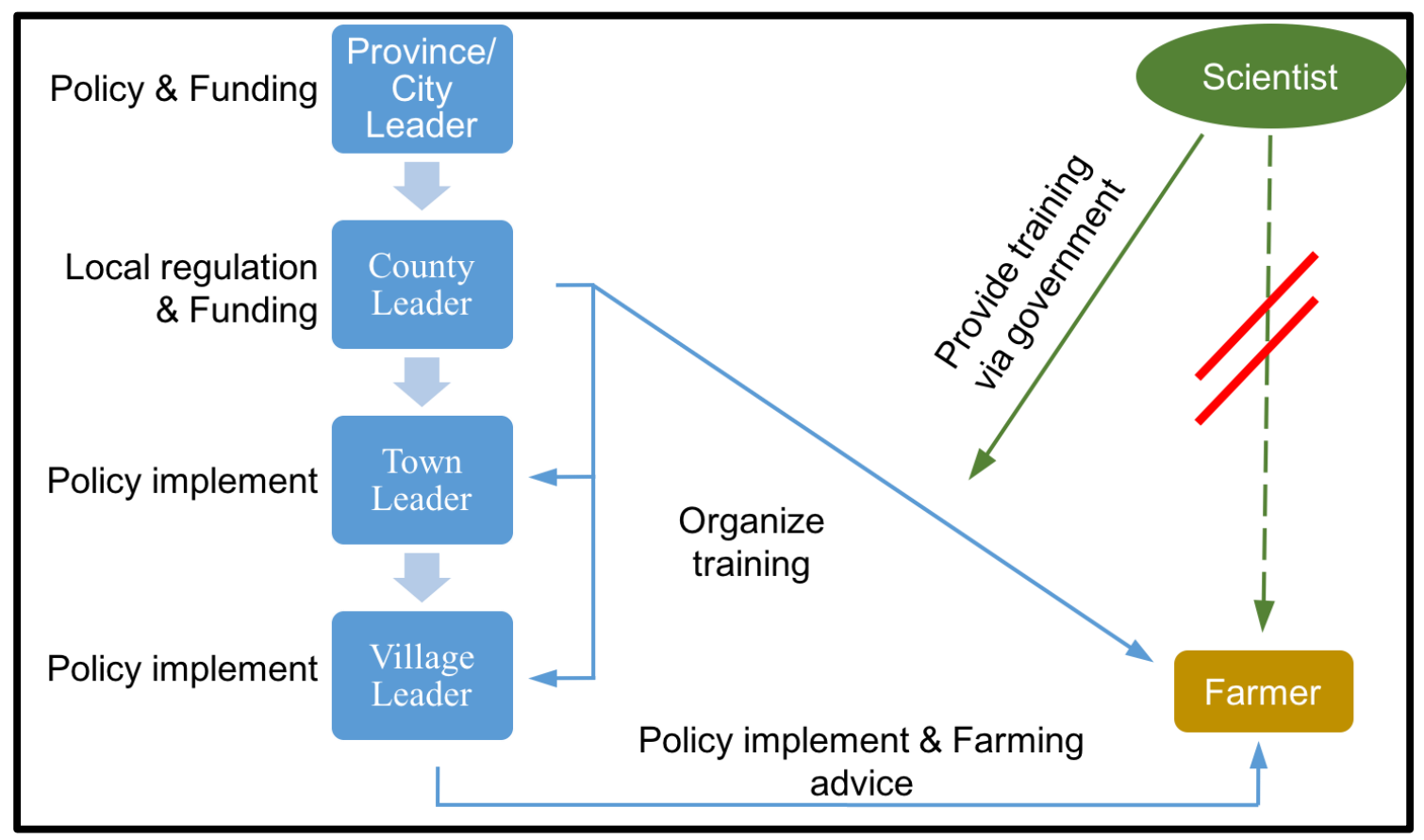

Figure 12. Science-policy-practice interface during knowledge exchange process in Puding County.

In the process of knowledge exchange, leaders from multi-levels showed different job roles. The province/city offices make high-level local policies for the environment and farming practice. Meanwhile they also provide funding for any proposed and permitted training events. County leaders perform the similar role in granting funding, although instead of making policies, they form local regulations. For these formed policies and regulations, it is more of the job for town and village leaders to take this information to the next level, and ultimately to farmers. However village leaders have more interaction with farmers to provide advice on farming activities.

Most training is organized by county leaders, and delivered directly to town/village leaders and to farmers. Here scientists get involved and provide training courses to the local publics. However the training usually happens in the form of seminar which is less favoured (the survey results showed farm visiting by experts/scientists is popular way by farmers). Additionally it is clear that there is no direct interaction or communication between scientists and users of science results (farmers), and it is not clear at this stage if this communication is a two-way interaction. Both of these may reduce the efficiency of knowledge flow in this interface.

\subsection{Main findings and recommendations}

- It is now clearer for both local practitioners and KE researchers to understand what level of governance to access and communicate with, to implement the different needs for KE delivery, e.g. organizing training or apply for funding.

- It would likely be beneficial to create more opportunities and channels to facilitate the direct communication between scientists/experts and farmers. This can help ensure that the provided training/knowledge properly meet the needs for farmers.

- It should be encouraged to foster a two-way knowledge sharing between scientists and users. This can be carried out by collecting feedback and suggestions from local public including farmers and town/village leaders. 


\section{Conclusion and next steps}

This report documents a better understanding about the local science users in the seven surveyed villages in Puding County, the KE approach preferred by different user groups and the sciencepolicy-practice interface during KE process. In the next step, this KE understanding will be shared with the local government, with the primary aim being to facilitate a more effective communication between researchers and non-researchers. In addition, a similar survey will be planned in one of the NERC-NSFC funded CZ projects outside Guizhou Province, to assess if this $\mathrm{KE}$ finding varies in different parts of China, or it is consistent and thus can be more widelyapplied across the country.

\section{References}

Brantley, S.L., Godhaber, M.B., Ragnarsdottir, K.V., 2007. Crossing disciplines and scales to understand the Critical Zone. Elements 3, 307-31.

Cvitanovic, C., Hobday, A.J., van Kerkhoff, L., Wilson, S.K., Dobbs, K., Marshall, N.A., 2015. Improving knowledge exchange among scientists and decision-makers to facilitate the adaptive governance of marine resources: A review of knowledge and research needs. Ocean \& Coastal Management 112, 25-35.

Fazey, I., Evely, A.C., Reed, M.S., Stringer, L.C., Kruijsen, J., White, P.C.L., Newsham, A., Jin, L., Cortazzi, M., Phillipson, J., Blackstock, K., Entwistle, N., Sheate, W., Armstrong, F., Blackmore, C., Fazey, J., Ingram, J., Gregson, J.O.N., Lowe, P., Morton, S., Trevitt, C., 2013. Knowledge exchange: a review and research agenda for environmental management. Environmental Conservation 40, 19-36.

Lin. Earth's Critical Zone and hydropedology: concepts, characteristics, and advances. Hydrol. Earth Syst. Sci., 14, 25-45, 2010.

Millennium Ecosystem Assessment (MA). 2005. Ecosystems and Human Well-Being: Synthesis [1]. Island Press, Washington. 